\title{
Properties of Concrete Containing Rubber Aggregate Derived From Discarded
} Tires

\author{
Nguyen Duc Luong ${ }^{1}$ \\ Hoang Vinh Long ${ }^{2}$ \\ Ngo Kim Tuan ${ }^{3}$ \\ Nguyen Duy Thai ${ }^{4}$

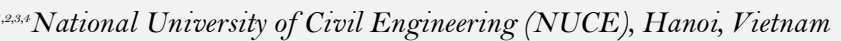

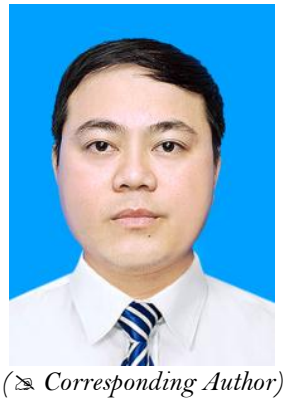

\begin{abstract}
This study carried out the experiment to evaluate the effects of different contents and sizes of rubber particles derived from discarded tires used for replacing fine and coarse natural aggregates, on the workability of fresh rubberized concrete and the compressive and flexural strengths of hardened rubberized concrete. The study results showed that the workability of fresh rubberized concrete was improved when replacing natural fine aggregate (sand) with fine rubber particles $(2.5-5 \mathrm{~mm})$ at the replacing proportions of $30-50 \%$ by volume, and when replacing natural coarse aggregate (crushed stone) with coarse rubber particles $(5-20 \mathrm{~mm})$ at the replacing proportions of $10-30 \%$ by volume. With respect to the mechanical properties of hardened rubberized concrete, a larger reduction in the compressive and flexural strengths was generally found when the replacing proportions increased and when coarse aggregate rather than fine aggregate was replaced by rubber particles at all replacing proportions (10-50\%). However, the study results also indicated that using fine rubber particles for replacing fine natural aggregate at the low replacing proportion (up to 10\%) might not cause the significant effect on the compressive and flexural strength of rubberized concrete.
\end{abstract}

Keywords: Discarded tire rubber, Fine and coarse rubber particle, Rubberized concrete, Workability, Mechanical properties.

Citation | Nguyen Duc Luong; Hoang Vinh Long; Ngo Kim Tuan; Nguyen Duy Thai (2017). Properties of Concrete Containing Rubber Aggregate Derived From Discarded Tires. Asian Review of Environmental and Earth Sciences, 4(1): 12-19.

History:

Received: 3 July 2017

Revised: 20 July 2017

Accepted: 12 August 2017

Published: 6 September 2017

Licensed: This work is licensed under a Creative Commons

Attribution 3.0 License (cc) Er

Publisher:Asian Online Journal Publishing Group
Contribution/Acknowledgement: This study is the major part of the research project "Studying light concrete using rubber aggregate recycled from discarded tires", B2015-03-16 (2015-2016).

Funding: The authors would like to thank the Vietnam Ministry of Education and Training that provided the financial support for conducting this project. Competing Interests: The authors declare that they have no conflict of interests. interests.

Transparency: The authors confirm that the manuscript is an honest, accurate, and transparent account of the study was reported; that no vital features of the study have been omitted; and that any discrepancies from the study as planned have been explained.

Ethical: This study follows all ethical practices during writing.

\section{Contents}

1. Introduction

2. Experimental Study

13

3. Results and Discussions

4. Conclusions

15

References. 


\section{Introduction}

It has been estimated that 1000 million tires reach the end of their useful life every year. By the year 2030, the number can reach up to 1200 million tires representing almost 5000 million tires (including stock piled) to be discarded on a regular basis [1]. The development and enforcement of regulations and guidance on collection, storage and separation, transport, processing, disposal, and recycling activities for discarded tires in several countries such as USA, Japan, Korea, and Taiwan has brought a number of environmental and economic benefits in those countries [2]. However, in many developing countries including Vietnam, there are lacking of such regulations and guidance in place. In these countries, discarded tires have been largely treated in unsustainable manners. At present, enormous quantities of discarded tires are already stockpiled (whole tire) or landfilled (shredded tire). Such stockpiles pose serious environmental and health threats which could have severe long-term effects if not properly addressed. Improperly stored tires are potential breeding grounds for disease-carrying insects and rodents. Discarded tire landfilling is responsible for a serious ecological threat. Mainly discarded tires disposal areas contribute to the reduction of biodiversity as the tires hold toxic and soluble components. Secondly although discarded tires are difficult to ignite, this risk is always present. Once tires start to burn down due to accidental causes, high temperature takes place and toxic fumes are generated which causes air pollution problem [3] besides the high temperature causes tires to melt, thus producing an oil that will contaminate soil and water [4]. In order to properly dispose of huge amount of discarded tires, use of innovative techniques to recycle them is important. Worldwide, discarded tires have been recycled for different purposes such as energy recovery (use of tire derived fuel in cement kilns, paper mills or power plants); tire pyrolysis for producing gas, oil, and char [5] civil engineering applications (lightweight fill for embankments and retaining walls, leachate drainage material and alternative daily cover at municipal solid waste landfills, insulating layer beneath roads and behind retaining walls, etc.) [6-9].

On the other hand, consumption of natural aggregates (river sand, stone, etc.) for concrete production is rapidly increasing in countries around the world in order to meet the increasing needs of infrastructural development in the recent years. Due to the overexploitation in many countries, the availability of these natural aggregates has been decreasing $[10,11]$. The increasing shortage of natural aggregates has created an opportunity for using by-products as fine aggregate. Reuse of waste rubber derived from discarded tires as a partial or full replacement of natural aggregates in construction activities not only reduces demand for exploitation of natural raw materials, but also reduces environmental pollution problems associated with disposal of discarded tires [12]. In this regard, a number of studies on the use of rubber aggregate derived from discarded tire for replacing natural aggregates in concrete have been conducted recently. Rubber aggregates are obtained from discarded tires using two different technologies: mechanical grinding at ambient temperature and/or cryogenic grinding at a temperature below the glass transition temperature [13, 14]. Although previous studies have achieved encouraging results, there are still several aspects related to the effects of replacing volume for traditional aggregates by rubber aggregate and the effects of size and shape of rubber particles on the mechanical properties of concrete, that need to be further studied. This paper presents the results of the first ever study in Vietnam which aims to investigate the effects of different contents and sizes of rubber particles derived from discarded tires used as aggregates for replacing fine and coarse natural aggregates on the workability of fresh rubberized concrete, the compressive and flexural strengths of hardened rubberized concrete.

Table-1. Major properties of materials

\begin{tabular}{|c|c|c|}
\hline Properties & Unit & Values \\
\hline \multicolumn{3}{|l|}{ 1. Portland cement $\mathrm{PC} 4 \mathrm{O}$} \\
\hline Fineness: particles retained on $90 \mu \mathrm{m}$ sieve & $\%$ & $\mathrm{O}$ \\
\hline Specific gravity & $\mathrm{g} / \mathrm{cm}^{3}$ & 3.10 \\
\hline Initial time of setting & Minute & 105.00 \\
\hline Final time of setting & Minute & 180.00 \\
\hline Compressive strength at 3 days $\pm 45 \mathrm{~min}$ & $\mathrm{MPa}$ & 28.80 \\
\hline Compressive strength at 28 days \pm 8 hours & $\mathrm{MPa}$ & 46.70 \\
\hline \multicolumn{3}{|l|}{ 2. Fly ash } \\
\hline Total content of $\mathrm{SiO}_{2}, \mathrm{Al}_{2} \mathrm{O}_{3}, \mathrm{Fe}_{2} \mathrm{O}_{3}$ & $\%$ & 90.51 \\
\hline Fineness: particles retained on $45 \mu \mathrm{m}$ sieve & $\%$ & 23.20 \\
\hline Water absorption & $\%$ & 2.00 \\
\hline $\begin{array}{l}\text { Strength activity index } \\
\text { - At } 7 \text { days } \\
\text { - At } 28 \text { days } \\
\end{array}$ & $\%$ & $\begin{array}{l}80.10 \\
84.80 \\
\end{array}$ \\
\hline \multicolumn{3}{|l|}{ 3. Sand } \\
\hline Specific gravity & $\mathrm{g} / \mathrm{cm}^{3}$ & 2.60 \\
\hline Water absorption & $\%$ & 2.10 \\
\hline Fineness modulus & $\mathrm{mm}$ & 2.65 \\
\hline \multicolumn{3}{|l|}{ 4. Crushed stone } \\
\hline Specific gravity & $\mathrm{g} / \mathrm{cm}^{3}$ & 2.65 \\
\hline Water absorption & $\%$ & 1.50 \\
\hline Fineness modulus & $\mathrm{mm}$ & 6.48 \\
\hline \multicolumn{3}{|l|}{ 5. Rubber } \\
\hline Specific gravity & $\mathrm{g} / \mathrm{cm}^{3}$ & 1.17 \\
\hline Water absorption & $\%$ & $\mathrm{O}$ \\
\hline $\begin{array}{l}\text { Particle size } \\
\text { - Fine } \\
\text { - Coarse }\end{array}$ & $\mathrm{mm}$ & $\begin{array}{c}2.50-5.00 \\
5.00-20.00\end{array}$ \\
\hline
\end{tabular}




\section{Experimental Study}

\subsection{Materials}

In this study, the ordinary Portland cement PC 40 and fly ash (FA) were used as the binders. The physical, chemical and mechanical properties of the Portland cement and FA are given in Table 1. The Portland cement PC 40 is produced by the local company named JSC Vicem But Son Cement with its properties determined according to [15-17]. The percentage of cement retained on a $90 \mu \mathrm{m}$ sieve as specified by Vietnam Standard [15] was $0 \%$. The FA was obtained from the local power plant (Pha Lai Power Plant in Hai Duong province, Northeast of Vietnam). According to ASTM C618-15 [18] the FA can be classified as a class F fly ash due to its chemical composition. In addition to having pozzolanic properties, this type of FA also has some cementitious properties. The total content of $\mathrm{SiO}_{2}, \mathrm{Al}_{2} \mathrm{O}_{3}$, and $\mathrm{Fe}_{2} \mathrm{O}_{3}$ in $\mathrm{FA}$ is $90.51 \%$, which is larger than the value given by the ASTM C618-15 standard for class F fly ash. The amount of FA retained on a $45 \mu \mathrm{m}$ sieve was $23.20 \%$, which is less than the value given in ASTM C618-15 standard [18].

Sand and crushed stone were used as fine and coarse aggregates in the concrete mix, respectively. The major properties of these materials were determined following [19] and given in Table 1. The sand used complies to the description of ASTM C778 [20] and its gradation was in agreement to the requirement of ASTM C33/C33M [21]. In this study, the size of crushed stone was in the range of 5-20 mm. Coarse (5-20 mm) and fine $(2.5-5 \mathrm{~mm})$ rubber particles used in the experiment were obtained from mechanical shredding of discarded tires. The physical properties of rubber particles are shown in Table 1.

\subsection{Concrete Mix Design}

Eleven different mix designs (Mo-M10) were considered in this study. The control design (Mo), containing no rubber, was determined using the absolute volume method, and consisted of $332 \mathrm{~kg}$ of cement, $58.5 \mathrm{~kg}$ of FA, 680 $\mathrm{kg}$ of sand (fine aggregate), $1200 \mathrm{~kg}$ of crushed stone (coarse aggregate), $155 \mathrm{~kg}$ of water, $2.73 \mathrm{~kg}$ of superplasticizer, and all per cubic meter of mix. The other five mixes (M1-M5) had fine aggregate replaced by fine rubber particle of equal volume, in $10 \%$ increments, up to $50 \%$ rubber replacement. Similarly, the remaining five mixes (M6-M10) had coarse aggregate replaced by coarse rubber particle of equal volume, in $10 \%$ increments, up to $50 \%$ rubber replacement.

Table-2. Concrete mix design (calculated for $1 \mathrm{~m}^{3}$ concrete)

\begin{tabular}{|c|c|c|c|c|c|c|c|c|c|c|}
\hline \multirow{2}{*}{$\begin{array}{c}\text { Mix } \\
\text { ID }\end{array}$} & \multirow{2}{*}{\begin{tabular}{|c|} 
Cement \\
$\begin{array}{c}\text { Weight } \\
(\mathrm{kg})\end{array}$ \\
\end{tabular}} & \multirow{2}{*}{$\begin{array}{c}\text { Fly ash } \\
\text { Weight } \\
\text { (kg) }\end{array}$} & \multirow{2}{*}{$\begin{array}{l}\text { Sand } \\
\text { Weight } \\
\text { (kg) }\end{array}$} & \multirow{2}{*}{$\begin{array}{l}\begin{array}{c}\text { Crushed } \\
\text { stone }\end{array} \\
\begin{array}{c}\text { Weight } \\
(\mathbf{k g})\end{array}\end{array}$} & \multirow{2}{*}{$\begin{array}{c}\text { Water } \\
\begin{array}{c}\text { Weight } \\
(\mathrm{kg})\end{array}\end{array}$} & \multicolumn{2}{|c|}{$\begin{array}{c}\text { Fine rubber } \\
\text { particle }\end{array}$} & \multicolumn{2}{|c|}{$\begin{array}{c}\text { Coarse rubber } \\
\text { particle }\end{array}$} & \multirow{2}{*}{$\begin{array}{c}\text { Superplasticizer } \\
\text { Weight } \\
(\mathrm{kg})\end{array}$} \\
\hline & & & & & & $\begin{array}{c}\text { Weight } \\
\text { (kg) }\end{array}$ & $\begin{array}{c}\text { \% by } \\
\text { volume } \\
\end{array}$ & $\begin{array}{c}\text { Weight } \\
(\mathrm{kg})\end{array}$ & $\begin{array}{c}\% \text { by } \\
\text { volume } \\
\end{array}$ & \\
\hline Mo & 332 & 58.5 & 680 & 1200 & 155 & $\mathrm{O}$ & $0 \%$ & $\mathrm{O}$ & $0 \%$ & 2.73 \\
\hline M1 & 332 & 58.5 & 612 & 1200 & 155 & 30.18 & $10 \%$ & 0 & $0 \%$ & 2.73 \\
\hline $\mathrm{M} 2$ & 332 & 58.5 & 544 & 1200 & 155 & 60.35 & $20 \%$ & 0 & $0 \%$ & 2.73 \\
\hline M5 & 332 & 58.5 & 340 & 1200 & 155 & 150.88 & $50 \%$ & $\mathrm{O}$ & $0 \%$ & 2.73 \\
\hline M6 & 332 & 58.5 & 680 & 1080 & 155 & 0 & $0 \%$ & 52.27 & $10 \%$ & 2.73 \\
\hline M7 & 332 & 58.5 & 680 & 960 & 155 & 0 & $0 \%$ & 104.53 & $20 \%$ & 2.73 \\
\hline M8 & 332 & 58.5 & 680 & 840 & 155 & 0 & $\mathrm{O} \%$ & 156.80 & $30 \%$ & 2.73 \\
\hline M9 & 332 & 58.5 & 680 & 720 & 155 & $\mathrm{O}$ & $0 \%$ & 209.07 & $40 \%$ & 2.73 \\
\hline
\end{tabular}

The amount of cement, FA, water, and superplasticizer were all held constant, to reduce the number of variables and maintain a water-to-cement ratio of 0.47 for all mixes. The weights of aggregates and rubber in each mix can be found in Table 2 .

\subsection{Specimen Preparation and Test Setup \\ a. Slump Test}

In order to evaluate the effect of rubber particles derived from discarded tires replacing natural aggregates on the workability of fresh rubberized concrete, slump tests were performed for all mixes (Table 2) according to Vietnam Standard [22].

\section{b. Compressive Strength Test}

The compressive strength tests were performed for all mixes according to Vietnam Standard [23] in order to evaluate the effect of fine and coarse aggregate replacement with fine and coarse rubber particles, respectively, on the compressive strength of hardened concrete. Mix proportions used to prepare specimens for the compressive strength tests were those presented in Table 2. One set of three cubic specimens with a side of $150 \mathrm{~mm}$ was realized for each mixture studied. Specimens were cast using appropriate moulds placed on a vibration table for 60 seconds in order to obtain a more homogeneous distribution of rubber particles in concrete mix. After casting, the moulds were left to cure for 24 hours. Once hardened, specimens were accurately demoulded, placed in a curing room at a relative humidity of $75 \%$ and a temperature of $27 \pm 2{ }^{\circ} \mathrm{C}$ until testing time. The compressive tests were then carried out for both 7 and 28 day aged specimens by an oil-pressure machine under loading control with a capacity of $3,000 \mathrm{kN}$ and the loading rate of $0.4 \mathrm{MPa} / \mathrm{s}$.

\section{c. Flexural Strength Test}

The flexural strength tests were also performed for all mixes according to Vietnam Standard [24] in order to evaluate the effect of fine and coarse aggregate replacement with fine and coarse rubber particles, respectively on the flexural strength of hardened concrete. Employed mix proportions for preparing specimens for the flexural 
strength tests were the same presented in Table 2. One set of three specimens with measuring $150 \times 150 \times 600 \mathrm{~mm}$ was cast for each mix design. The casting and curing procedures were similar to those reported above for the compressive strength tests. For the flexural strength test, three specimens from each mix design were tested by one-point loading configuration with a span of $10 \mathrm{~cm}$ using testing machine with a capacity of $10 \mathrm{kN}$ and the loading rate of $0.06 \mathrm{MPa} / \mathrm{s}$. All tests were carried out 28 days after casting.

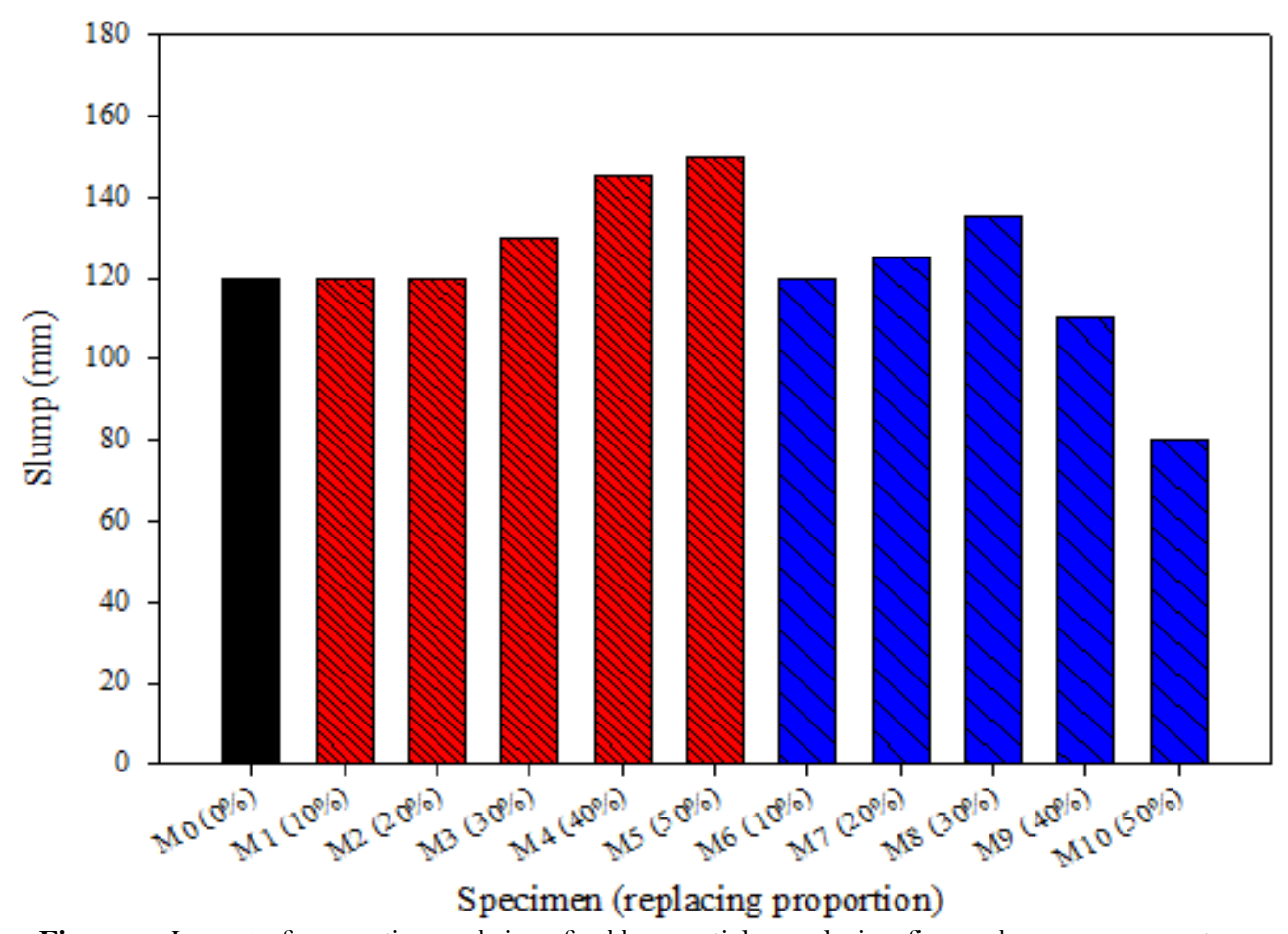

Figure-1. Impact of proportion and size of rubber particles replacing fine and coarse aggregates on slump of fresh rubberized concrete

\section{Results and Discussions}

\subsection{Workability of Fresh Rubberized Concrete}

The results of slump tests are shown in Figure 1. When sand (fine aggregate) was replaced by fine rubber particle at the low proportions ( $10 \%$ and $20 \%$ by volume), it can be seen that the slumps or workability of fresh rubberized concrete were not changed much compared to that of the control mix (Mo). At the higher replacing proportions $(30 \%, 40 \%$ and $50 \%$ by volume), the slumps relatively increased. Our results are in good agreement with those reported by previous studies [25-29] where the workability of fresh rubberized concrete increased with increasing rubber contents. For instances, Aiello and Leuzzi [26] showed that the workability of rubberized concrete was slightly improved when coarse or fine aggregates were partially replaced with rubber shreds. They reported that the control concrete exhibited a fluid behavior, while the rubberized concrete showed a hyper-fluid behavior. Similarly, Balaha, et al. [25] used ground waste tire rubber for partial replacement of natural sand at the proportions of $0 \%, 5 \%, 10 \%, 15 \%$ and $20 \%$, by volume and they reported that the workability increased as rubber sand content increased. However, it is worth to note that the other studies reported contrary results with the decreased workability as rubber aggregates included in the concrete mixture [30-33].

When crushed stone (coarse aggregate) was partially replaced by coarse rubber particle at the low and medium proportions $(10 \%, 20 \%$, and $30 \%$ by volume), it was observed that the slumps slightly increased in comparing to that of the control mix. However, when the replacing proportion increased to $40 \%$, the slump slightly decreased. Especially, at the replacing proportion of $50 \%$, the slump was found to be decreased significantly. This can be explained that when coarse rubber particles were used at high proportion, the contacts among coarse rubber particles and among rubber particles with other aggregates increased leading to the increase in the inter-particle friction between rubber particles and other aggregates, thus reduce the workability of fresh rubberized concrete. Our slump test results for the case of coarse rubber particle replacing coarse aggregate are also similar to those reported by the other studies [1,34-40]. Turgut and Yesilata [35] partially replaced sand in concrete block mixtures with rubber aggregate at the proportions ranging from $10 \%$ to $70 \%$ with an increment of $10 \%$, by volume. Their results showed that the workability increased with the inclusion of rubber aggregate up to $40 \%$, whereas the inclusion of 50-70\% rubber aggregate caused the decreased workability. Pacheco-Torgal, et al. [1] reported that when rubber chips used to partially replace for coarse aggregate, the slump increased with increasing volume of rubber aggregates up to the replacing proportion of $15 \%$, and the slump decreased as the replacing proportions were larger than $15 \%$ by volume. Compared results on the workability of fresh rubberized concrete between this study and other studies suggest that the workability may be largely dependent on the specific characteristics of the rubber aggregates used in the concrete mixture. Therefore, future studies should focus more on the characteristics of rubber aggregates (size, shape, pretreatment of rubber aggregates, etc.) that influence the workability of rubberized concrete. 


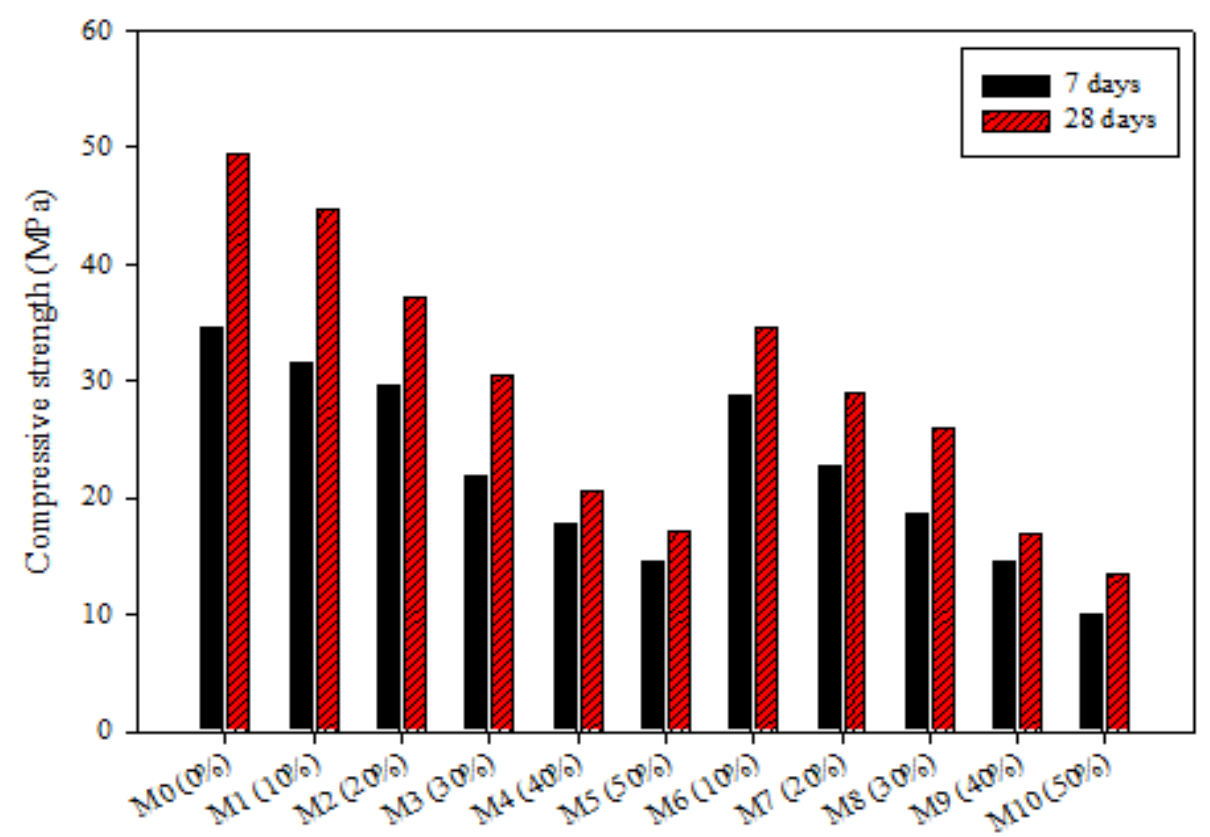

Specimen (replacing proportion)

Figure-2. Impact of replacing proportion and size of rubber particles on compressive strength of hardened rubberized concrete

\subsection{Mechanical Properties of Hardened Rubberized Concrete \\ a. Compressive Strength}

The 7-day and 28-day compressive strengths as a function of different replacing proportions of rubber particles with different sizes are presented in Figure 2. As expected, the compressive strength increased with curing time for the control specimen (Mo) and other specimens (M1-M10) at all replacing proportions. The compressive strength of the control specimen was evaluated as 34.5 and $49.5 \mathrm{MPa}$ at 7 and 28 days, respectively. The test results indicated that there was a significant reduction in the compressive strength of rubberized concrete as the rubber content increased in comparison to that of the control specimen at both 7 and 28 days.

Table-3. Reduction (\%) in compressive strength of rubberized concrete compared to plain concrete

\begin{tabular}{|c|c|c|c|c|c|c|c|}
\hline & \multirow[t]{2}{*}{ Cured time (day) } & \multicolumn{6}{|c|}{$\begin{array}{c}\text { Specimen } \\
\text { (Proportion of natural aggregates replaced with } \\
\text { rubber particles, } \% \text { by volume) }\end{array}$} \\
\hline & & $\begin{array}{c}\text { M0 } \\
(0 \%)\end{array}$ & $\begin{array}{c}\text { M1 } \\
(10 \%)\end{array}$ & $\begin{array}{c}\text { M2 } \\
(20 \%)\end{array}$ & $\begin{array}{c}\text { M3 } \\
(\mathbf{3 0} \%)\end{array}$ & $\begin{array}{c}\text { M4 } \\
(40 \%)\end{array}$ & $\begin{array}{c}\text { M5 } \\
(\mathbf{5 0 \%})\end{array}$ \\
\hline \multirow{3}{*}{$\begin{array}{l}\text { Reduction (\%) in compressive } \\
\text { strength of rubberized concrete } \\
\text { using fine rubber particle to } \\
\text { replace fine aggregate }\end{array}$} & 7 & 0 & 8.7 & 14.2 & 36.5 & 48.4 & 57.7 \\
\hline & 28 & 0 & 9.7 & 24.8 & 38.2 & 58.4 & 65.5 \\
\hline & & $\begin{array}{c}\text { M0 } \\
(0 \%)\end{array}$ & $\begin{array}{c}\text { M6 } \\
(10 \%)\end{array}$ & $\begin{array}{c}\text { M7 } \\
(20 \%)\end{array}$ & $\begin{array}{c}\text { M8 } \\
(30 \%)\end{array}$ & $\begin{array}{c}\text { M9 } \\
(40 \%)\end{array}$ & $\begin{array}{c}\text { M10 } \\
(50 \%)\end{array}$ \\
\hline \multirow{2}{*}{$\begin{array}{l}\text { Reduction }(\%) \text { in compressive } \\
\text { strength of rubberized concrete } \\
\text { using coarse rubber particle to } \\
\text { replace coarse aggregate }\end{array}$} & 7 & 0 & 16.2 & 34.2 & 45.8 & 58.0 & 71.0 \\
\hline & 28 & 0 & 30.3 & 41.4 & 47.5 & 65.7 & 72.7 \\
\hline
\end{tabular}

It is found that depending on the proportion and size of replacing rubber particles, the degree of reduction in the compressive strength was different (Table 3). At the replacing proportion of $10 \%$, the reduction in the compressive strength of the specimens containing fine rubber particles at 7 and 28 days were 8.7 and $9.7 \%$, respectively; whilst the counterpart for the specimens containing coarse rubber particles at 7 and 28 days were 16.2 and $30.3 \%$, respectively. This suggests that using coarse rubber particles lowered the compressive strength of rubberized concrete more than the case of using fine rubber particles. When the replacing proportions increased to 20,30 , and $40 \%$ by volume, the compressive strengths also decreased accordingly, however, the degrees of reduction between two cases (the specimens containing fine and coarse rubber particles) at the same replacing proportions gradually became smaller than that at the replacing proportion of $10 \%$, especially for the specimens at the curing time of 28 days. The replacing proportion of $50 \%$ caused the largest reductions in the compressive strength of specimens containing fine and coarse rubber particles at both 7 and 28 days. The test results imply that using fine rubber particles, instead of fine natural aggregate, at the low replacing proportion (up to 10\%) might not cause the significant effect on the compressive strength of rubberized concrete. Overall, our results agreed well with previous studies which reported that the inclusion of increasing rubber contents caused progressive losses in the compressive strength of rubberized concrete and the replacement of coarse aggregate in the concrete mixture lowered the compressive strength more than that of fine aggregate [26, 31, 40-44].

There are several possible reasons for the reduction in the compressive strength of rubberized concrete which largely influenced by the physical and mechanical properties of constituent aggregates. First, it could be attributed to the physical properties of rubber particles which are less stiff than cement paste. This could lead to the deformability of rubber particles compared with surrounding cement paste that resulted in the rapid development of cracks around rubber particles in a fashion similar to that occurring with air voids in normal concrete [41, 45, 46]. The second reason for the decrease in the compressive strength is the poor bond between rubber particles and 
cement paste in comparing to the bond between natural aggregates and cement paste. Corinaldesi, et al. [47] and Raj, et al. [48] indicated that the low strength of rubberized concrete is due to the weak interface or transition zone between rubber particles and cement paste. Such a weak interface could initially cause micro-cracks which eventually grow to macro-cracks, and result in the failure of rubberized concrete specimen under compression. Our test results showed the surfaces of the failed specimens having quite clean rubber particles with little cement paste attached which implies the poor bond between rubber particles and cement paste. The third reason for the reduction in the compressive strength of rubberized concrete might be associated with the low specific gravity of rubber, coupled with the poor bond of rubber particles with other aggregates, which might make rubber particles moving upwards during vibration in the casting process and concentrating at the top layer of the specimen. This could result in a non-homogeneous distribution of rubber particles and other aggregates, and therefore reduce the strength of the specimen. The other reason for the decreased compressive strength could be the increased matrix porosity or weakness points in rubberized concrete matrix which largely depending on the size, density, and hardness of aggregates as explained by the previous studies $[45,49,50]$.

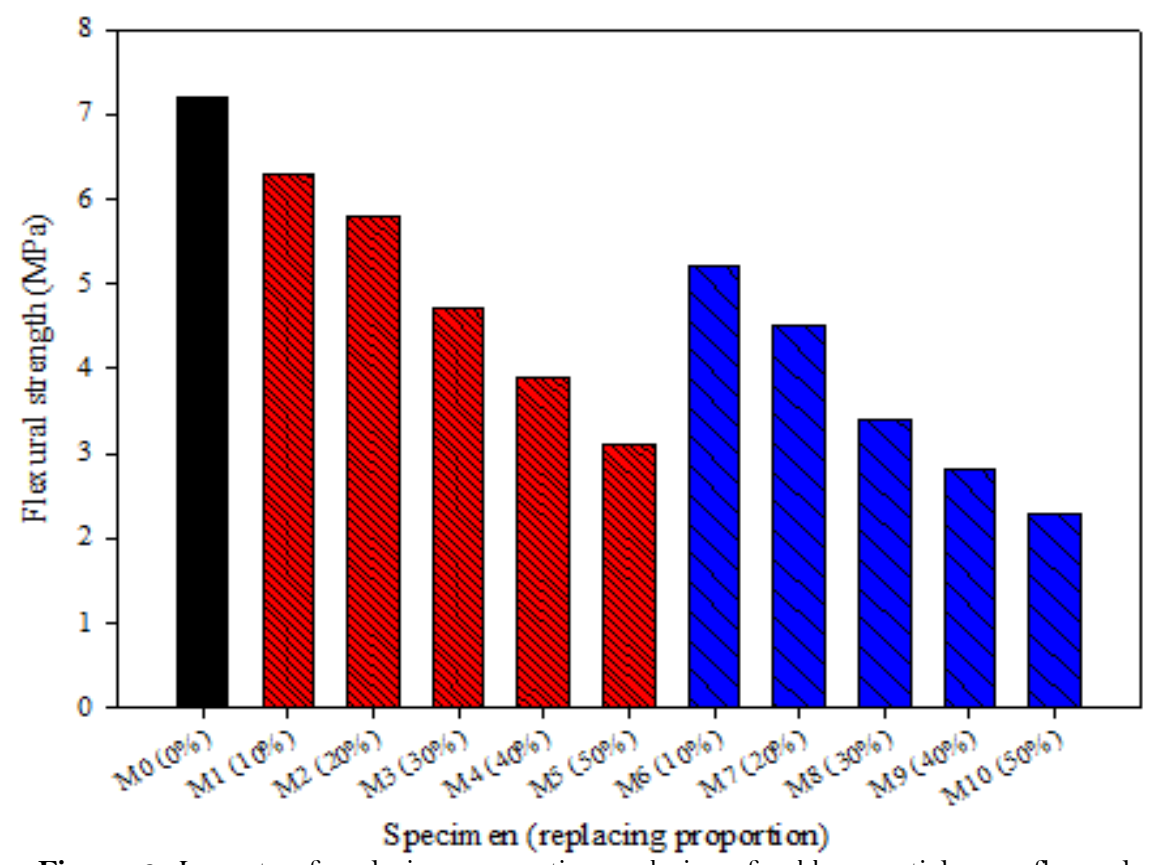

Figure-3. Impacts of replacing proportion and size of rubber particles on flexural strength at 28 days of hardened rubberized concrete

\section{b. Flexural Strength}

The influences of different replacing proportions and different sizes of rubber particles on the 28-day flexural strengths of rubberized concrete are presented in Figure 3. The flexural strength at 28 days of the control specimen was 7.2 MPa. Similar to the case of the compressive strength, the test results indicated that there were significant reductions in the flexural strength of rubberized concrete specimens compared to the control specimen when replacing proportions increased.

Table-4. Reduction (\%) in flexural strength at 28 days of rubberized concrete compared to plain concrete

\begin{tabular}{|c|c|c|c|c|c|c|}
\hline & \multicolumn{6}{|c|}{$\begin{array}{c}\text { Specimen } \\
\text { (Proportion of natural aggregates replaced with } \\
\text { rubber particles, \% by volume) }\end{array}$} \\
\hline & $\begin{array}{c}\text { M0 } \\
(0 \%) \\
\end{array}$ & $\begin{array}{c}\text { M1 } \\
(10 \%)\end{array}$ & $\begin{array}{c}\text { M2 } \\
(20 \%)\end{array}$ & $\begin{array}{c}\text { M3 } \\
(30 \%)\end{array}$ & $\begin{array}{c}\text { M4 } \\
(40 \%) \\
\end{array}$ & $\begin{array}{c}\text { M5 } \\
(50 \%) \\
\end{array}$ \\
\hline \multirow{2}{*}{$\begin{array}{l}\text { Reduction }(\%) \text { in flexural strength of } \\
\text { rubberized concrete using fine rubber } \\
\text { particle to replace fine aggregate }\end{array}$} & 0 & 12.5 & 19.4 & 34.7 & 45.8 & 56.9 \\
\hline & $\begin{array}{c}\text { M0 } \\
(0 \%)\end{array}$ & $\begin{array}{c}\text { M6 } \\
(10 \%)\end{array}$ & $\begin{array}{c}\text { M7 } \\
(20 \%)\end{array}$ & $\begin{array}{c}\text { M8 } \\
(30 \%)\end{array}$ & $\begin{array}{c}\text { M9 } \\
(40 \%)\end{array}$ & $\begin{array}{c}\text { M10 } \\
(50 \%)\end{array}$ \\
\hline $\begin{array}{l}\text { Reduction }(\%) \text { in flexural strength of } \\
\text { rubberized concrete using coarse rubber } \\
\text { particle to replace coarse aggregate }\end{array}$ & 0 & 27.8 & 37.5 & 52.8 & 61.1 & 68.1 \\
\hline
\end{tabular}

The degree of reduction in the flexural strength was also largely influenced by the size of replacing rubber particles as shown in Table 4. As expected, a smaller reduction of the flexural strength was observed when fine aggregate was replaced by fine rubber particle, compared to the case of coarse rubber particle, for all replacing proportions. This could be attributed to the filling effect of fine rubber particles that increase the compactness of rubberized concrete specimens, reduce the stress singularity at internal voids, and thus reduce the likelihood of fracture [51]. The test results suggest that using fine rubber particles for replacing fine natural aggregate at the low replacing proportion (up to $10 \%$ ) might not cause the significant effect on the flexural strength of rubberized concrete which similar to the case of the compressive strength.

Similar test results were reported by the previous studies [26, 41, 51]. For instances, Aiello and Leuzzi [26] reported that rubberized concrete with the inclusion of $50 \%$ and $75 \%$ by volume of coarse aggregate replacement presented $28 \%$ decrease in the flexural strength compared to plain concrete. Whereas, rubberized concrete obtained with $50 \%$ and $75 \%$ by volume of fine aggregate replacement showed a decrease in the flexural strength of about $5.8 \%$ and $7.3 \%$, respectively compared to plain concrete. However, it is worth to note that the other studies have 
reported quite different results compared to ours with the increased flexural strength of rubberized concrete when rubber aggregate used to replace fine aggregate at the low replacing proportions (mainly less than $20 \%$ by volume), and the decreased flexural strength at the high replacing proportions. For instances, Yilmaz and Degirmenci [42] reported that rubberized concrete specimens using tire rubber (in the form of fibers) up to $20 \%$ by volume showed the higher flexural strength than control specimens, and the flexural strength decreased as rubber contents increased from 20-30\%. Gupta, et al. [52] reported that the flexural strength of rubberized concrete containing rubber ash decreased as the content of rubber ash increased, whereas the flexural strength of modified concrete (containing 10\% rubber ash and a varying content of rubber fibers) increased with the increasing content of rubber fibers. These studies showed that the increased flexural strength of rubberized concrete associated with the use of tire rubber in the form of fibers. This further suggests that future studies should focus on the characteristics of the rubber aggregates that enhance the flexural strength of rubberized concrete.

\section{Conclusions}

This study has conducted the experiment to investigate the properties of fresh and hardened rubberized concrete made by replacing natural aggregates with rubber particles derived from discarded tires having similar sizes of replaced natural aggregates. The major findings of this study can be summarized as the following:

- The workability of fresh rubberized concrete improved when replacing natural fine aggregate with fine rubber particles at the replacing proportions of $30-50 \%$ by volume, and when replacing natural coarse aggregate with coarse rubber particles at the replacing proportions of $10-30 \%$ by volume;

- With respect to the mechanical properties of hardened rubberized concrete, a larger reduction in the compressive and flexural strengths was generally observed when replacing proportions increased, and especially when coarse aggregate rather than fine aggregate was replaced by rubber particles at all replacing proportions (10-50\% by volume).

- Using fine rubber particles for replacing fine natural aggregate at the low replacing proportion (up to $10 \%$ ) might not cause the significant effect on the compressive and flexural strength of rubberized concrete.

Based on the findings of this study, further studies are recommended to verify the workability and the mechanical properties of rubberized concrete mixtures prepared by partially replacing both natural coarse and fine aggregates, and to evaluate effects of specific characteristics (e.g. size, shape, pretreatment) of rubber aggregates on the workability and the mechanical properties of rubberized concrete, especially characteristics that could increase the mechanical properties of rubberized concrete.

\section{References}

[1] F. Pacheco-Torgal, Y. Ding, and S. Jalali, "Properties and durability of concrete containing polymeric wastes (Tyre Rubber and Polyethylene Terephthalate Bottles): An overview," Constr Build Mater, vol. 30, pp. 714-724, 2012. View at Google Scholar | View at Publisher J. W. Jang, T. S. Yoo, J. H. Oh, and I. Iwasaki, "Discarded tire recycling practices in the United States, Japan and Korea," Resources, Conservation and Recycling, vol. 22, pp. 1-14, 1998. View at Google Scholar | View at Publisher

[3] K. E. Day, K. E. Holtze, S. J. L. Metcalfe, C. T. Bishop, and B. J. Dutka, "Toxicity of leachate from automobile tyres to aquatic biota," Chemosphere, vol. 27, pp. 665-675, 1993. View at Google Scholar | View at Publisher

[4] T. Amari, N. J. Themelis, and I. K. Wernick, "Resource recovery from used rubber tires," Resour Policy, vol. 25, pp. 179-188, 1999. View at Google Scholar | View at Publisher

[5] X. Shu and B. S. Huang, "Recycling of waste tire rubber in asphalt and port land cement concrete: An overview," Construction and Building Materials, vol. 67, pp. 217-224, 2014. View at Google Scholar | View at Publisher

[6] M. R. Merino, C. A. J. Santa, and C. M. González, "Viability analysis and constructive applications of lightened mortar rubber cement mortar," Construction and Building Materials, vol. 21, pp. 1785-1791, 2007. View at Google Scholar |View at Publisher [7] N. Al-Akhras and M. M. Samadi, "Properties of tire rubber ash mortar," Cement and Concrete Composites, vol. 26, pp. 82 1-826, 2004.
View at Google Scholar | View at Publisher A. Benazzouk, O. Douzane, and M. Quéneudec, "Transport
vol. 26, pp. 21-29, 2004. View at Google Scholar View at Publisher

[9] S. H. Chen, H. Y. Wang, and J. W. Jhou, "Investigating the properties of lightweight concrete containing high contents of recycled green building materials," Construction and Building Materials, vol. 48, pp. 98-103, 2013. View at Google Scholar $\mid$ View at Publisher

[10] A. M. Rashad, "A preliminary study on the effect of fine aggregate replacement with metakaolin on strength and abrasion resistance of concrete," Construction and Building Materials, vol. 44, pp. 448-495, 2013. View at Google Scholar $\mid$ View at Publisher

[11] A. M. Rashad, "Recycled waste glass as fine aggregate replacement in cementitious materials based on Portland cement," Construction and Building Materials, vol. 72, pp. 340-357, 2014. View at Google Scholar $\mid$ View at Publisher

[12] A. M. Rashad, "A comprehensive overview about recycling rubber as fine aggregate replacement in traditional cementitious materials," International Journal of Sustainable Built Environment, vol. 5, pp. 46-82, 2016. View at Google Scholar | View at Publisher

[13] K. Nagdi, Rubber as an engineering material: Guidelines for user. Munich; New York: Hanser Publication, 1993.

[14] W. Eleazer, M. Barlaz, and D. Whittle, Resource recovery alternatives for waste tires in North Carolina. US: School of Engineering, Civil Engineering Department, NCSU, 1992.

[15] Vietnam Standard, "TCVN 4030-2003 cement - test method for determination of fineness in Vietnamese," Vietnam Ministry of Science and Technology, 2003.

[16] Vietnam Standard, "TCVN 6017-1995 (ISO 9597:1989) cements - test methods - determination of setting time and soundness in Vietnamese," Vietnam Ministry of Science Technology and Environment, 1995.

[17] Vietnam Standard, "TCVN 6016-2011 (ISO 679:2009) cements - test methods - determination of strength in Vietnamese," Vietnam Ministry of Science and Technology, 2011.

[18] ASTM, ASTM C618-15 standard specification for coal fly ash and raw or calcined, natural pozzolan for use in concrete. West Conshohocken, PA, USA: ASTM International, 2015.

[19] Vietnam Standard, "TCVN 7572-4:2006 aggregates for concrete and mortar - test methods - part 4: Determination of apparent specific gravity, bulk specific gravity and water absorption in Vietnamese," Vietnam Ministry of Science and Technology, 2006.

[20] ASTM, ASTM C778-13 standard specification for standard sand. West Conshohocken, PA: ASTM International, 2013.

[21] ASTM, ASTM C33/C33M-16e1 standard specification for concrete aggregates. West Conshohocken, PA: ASTM International, 2016.

[22] Vietnam Standard, "TCVN 3106:1993 heavyweight concrete compounds - slump test in Vietnamese," Vietnam Ministry of Science Technology and Environment, 1993.

[23] Vietnam Standard, "TCVN 3118:1993 heavyweight concrete - method for determination of compressive strength in Vietnamese," Vietnam Ministry of Science Technology and Environment, 1993.

[24] Vietnam Standard, "TCVN 3119:1993 heavyweight concrete - method for determination of flexural tensile strength in Vietnamese," Vietnam Ministry of Science Technology and Environment, 1993.

[25] M. M. Balaha, A. A. M. Badawy, and M. Hashish, "Effect of using ground tire rubber as fine aggregate on the behaviour of concrete mixes," Indian Journal of Engineering and Materials Sciences, vol. 14, pp. 427-435, 2007. View at Google Scholar 
[26] M. A. Aiello and F. Leuzzi, "Waste tyre rubberized concrete: Properties at fresh and hardened state," Waste Management, vol. 30, pp. 1696-1704, 2010. View at Google Scholar | View at Publisher

[27] F. Pelisser, A. Barcelos, D. Santos, M. Peterson, A. Michael, and A. Bernardin, "Lightweight concrete production with low Portland cement consumption," Journal of Cleaner Production, vol. 23, pp. 68-74, 2012. View at Google Scholar $\mid$ View at Publisher

[28] O. Onuaguluchi and D. K. Panesar, "Hardened properties of concrete mixtures containing pre-coated crumb rubber and silica fume," Journal of Cleaner Production, vol. 82, pp. 125-131, 2014. View at Google Scholar $\mid$ View at Publisher

[29] M. Elchalakani, "High strength rubberized concrete containing silica fume for the construction of sustainable road side barriers," Structures, vol. 1, pp. 20-38, 2015. View at Google Scholar $\mid$ View at Publisher

[30] N. Ganesan, J. B. Raj, and A. P. Shashikala, "Flexural fatigue behavior of self-compacting rubberized concrete," Construction and Building Materials, vol. 44, pp. 7-14, 2013. View at Google Scholar | View at Publisher

[31] N. Holmes, A. Browne, and C. Montague, "Acoustic properties of concrete panels with crumb rubber as a fine aggregate replacement," Construction and Building Materials, vol. 73, pp. 195-204, 2014. View at Google Scholar |View at Publisher

[32] Z. Grdić, G. Topličić-Ćurčić, N. Ristić, D. Grdić, and P. Mitković, "Hydro-abrasive resistance and mechanical properties of rubberized concrete," Gradeinar, vol. 66, pp. 11-20, 2014. View at Google Scholar $\mid$ View at Publisher

[33] I. Mohammadi, H. Khabbaz, and K. Vessalas, "In-depth assessment of crumb rubber concrete (CRC) prepared by water-soaking treatment method for rigid pavements," Construction and Building Materials, vol. 71, pp. 456-471, 2014. View at Google Scholar $\mid$ View at Publisher

[34] A. R. Khaloo, M. Dehestani, and P. Rahmatabadi, "Mechanical properties of concrete containing a high volume of tire-rubber particles," Waste Management, vol. 28, pp. 2472-2482, 2008. View at Google Scholar | View at Publisher

[35] P. Turgut and B. Yesilata, "Physico-mechanical and thermal performance of newly developed rubber-added bricks," Energy Build, vol. 40, pp. 679-688, 2008. View at Google Scholar $\mid$ View at Publisher

[36] S. D. Parveen, D. Sachin, and S. Ankit, "Rubberized concrete: Needs of good environment overview," International Journal of Emerging Technology and Advanced Engineering, vol. 3, pp. 192-196, 2013. View at Google Scholar

[37] H. Y. Wang, B. T. Chen, and Y. W. Wu, "A study of the fresh properties of controlled low-strength rubber lightweight aggregate concrete CLSRLC," Construction and Building Materials, vol. 41, pp. 526-531, 2013. View at Google Scholar $\mid$ View at Publisher

[38] Y. Antil, V. Verma, and B. Singh, "Rubberized concrete with crumb rubber," International Journal of Science and Research, vol. 3, pp. $1481-1483,2014$

[39] Y. C. Guo, J. H. Zhang, G. M. Chen, and Z. H. Xie, "Compressive behaviour of concrete structures incorporating recycled concrete aggregates, rubber crumb and reinforced with steel fibre, subjected to elevated temperatures," Journal of Cleaner Production, vol. 72 , pp. 193-203, 2014. View at Google Scholar | View at Publisher

[40] O. Youssf, M. A. ElGaeady, J. E. Mills, and X. Ma, "An experimental investigation of crumb rubber concrete confined by fibre reinforced polymer tubes," Construction and Building Materials, vol. 53, pp. 522-532, 2014. View at Google Scholar |View at Publisher

[41] E. Ganjian, M. Khorami, and A. A. Maghsoudi, "Scrap-tyre-rubber replacement for aggregate and filler in concrete," Construction and Building Materials, vol. 23, pp. 1828-1836, 2009. View at Google Scholar | View at Publisher

[42] A. Yilmaz and N. Degirmenci, "Possibility of using waste tire rubber and fly ash with Portland cement as construction materials," Waste Management, vol. 29, pp. 1541-1546, 2009. View at Google Scholar $\mid$ View at Publisher

[43] F. Pelisser, Z. Nilomar, L. Tiago, A. Bernardin, and A. Michael, "Concrete made with recycled tire rubber: Effect of alkaline activation and silica fume addition," Journal of Cleaner Production, vol. 196, pp. 757-763, 2011. View at Google Scholar $\mid$ View at Publisher

[44] M. Gesoğlu, E. Güneyisi, G. Khoshnaw, and S. İpek, "Investigating properties of pervious concretes containing waste tire rubbers," Construction and Building Materials, vol. 63, pp. 206-213, 2014. View at Google Scholar $\mid$ View at Publisher

[45] M. M. Taha, A. S. El-Dieb, M. A. AbdEl-Wahab, and M. E. Abdel-Hameed, "Mechanical, fracture, and microstructural investigations of rubber concrete," Journal of Materials in Civil Engineering, vol. 20, pp. 640-649, 2008. View at Google Scholar $\mid$ View at Publisher

[46] B. S. Thomas and R. C. Gupta, "A comprehensive review on the applications of waste tire rubber in cement concrete," Renewable \& Sustainable Energy Reviews, vol. 54, pp. 1323-1333, 2016. View at Google Scholar | View at Publisher

[47] V. Corinaldesi, A. Mazzoli, and G. Moriconi, "Mechanical behaviour and thermal conductivity of mortars containing waste rubber particles," Materials \&̊ Design, vol. 32, pp. 1646-1650, 2011. View at Google Scholar | View at Publisher

[48] B. Raj, N. Ganesan, and A. P. Shashikala, "Engineering properties of self-compacting rubberized concrete," Journal of Reinforced Plastics and Composites, vol. 30, pp. 1923-1930, 2011 . View at Google Scholar $\mid$ View at Publisher

[49] C. Albano, N. Camacho, J. Reyes, J. L. Feliu, and M. Hernández, "Influence of scrap rubber to Portland I concrete composites: Destructive and non-destructive testing," Composite Structures, vol. 71, pp. 439-446, 2005. View at Google Scholar |View at Publisher

[50] M. Turki, E. Bretagne, M. J. Rouis, and M. Quéneudec, "Microstructure, physical and mechanical properties of mortar-rubber aggregates mix tures," Construction and Building Materials, vol. 23, pp. 2715-2722, 2009. View at Google Scholar $\mid$ View at Publisher

[51] H. Su, J. Yang, T. C. Ling, G. S. Ghataora, and S. Dirar, "Properties of concrete prepared with waste tyre rubber particles of uniform and varying sizes," Journal of Cleaner Production, vol. 91, pp. 288-296, 2014.

[52] T. Gupta, S. Chaudhary, and R. K. Sharma, "Assessment of mechanical and durability properties of concrete containing waste rubber tire as fine aggregate," Construction and Building Materials, vol. 73, pp. 562-574, 2014. View at Google Scholar | View at Publisher 